\title{
Transforming growth factor beta-I decreases the yield of the second meiotic division of rat pachytene spermatocytes in vitro Anne Damestoy ${ }^{1}$, Marie-Hélène Perrard ${ }^{\dagger 1}$, Michèle Vigier ${ }^{\dagger 1}$, Odile Sabido ${ }^{2}$ and Philippe Durand*1
}

Address: ${ }^{1}$ INSERM U418; INRA UMR1245; Université Claude-Bernard Lyon 1, 29 rue sœur Bouvier, 69322 Lyon cedex 05, France and ${ }^{2}$ Centre commun de Cytométrie en Flux, Faculté de Médecine, Université Jean Monnet, 42023 St Etienne, France

Email: Anne Damestoy - damestoy@lyon.inserm.fr; Marie-Hélène Perrard - perrard@lyon.inserm.fr; Michèle Vigier - vigier@lyon.inserm.fr; Odile Sabido - Odile.Sabido@univ-st-etienne.fr; Philippe Durand* - durand@lyon.inserm.fr

* Corresponding author †Equal contributors

Published: 07 June 2005

Reproductive Biology and Endocrinology 2005, 3:22 doi:I0.1 I86/1477-7827-3-

22

This article is available from: http://www.rbej.com/content/3/I/22

(C) 2005 Damestoy et al; licensee BioMed Central Ltd.

This is an Open Access article distributed under the terms of the Creative Commons Attribution License (http://creativecommons.org/licenses/by/2.0), which permits unrestricted use, distribution, and reproduction in any medium, provided the original work is properly cited.
Received: 29 March 2005

Accepted: 07 June 2005

\begin{abstract}
Background: TGF beta and its receptors are present in both germ cells and somatic cells of the male gonad. However, knock-out strategies for studying spermatogenesis regulation by TGF beta have been disappointing since TGF beta-or TGF beta receptor-null mice do not survive longer than a few weeks.
\end{abstract}

Methods: In the present study, we addressed the role of TGF beta-I on the completion of meiosis by rat pachytene spermatocytes (PS) cocultured with Sertoli cells. Identification and counting of meiotic cells were performed by cytology and cytometry.

Results: Under our culture conditions, some PS differentiated into round spermatids (RS). When TGF beta-I was added to the culture medium, neither the number of PS or of secondary spermatocytes nor the half-life of RS was modified by the factor. By contrast, the number of RS and the amount of TPI mRNA were lower in TGF beta-I-treated cultures than in control cultures. Very few metaphase I cells were ever observed both in control and TGF beta-I-treated wells. Higher numbers of metaphase II were present and their number was enhanced by TGF beta-I treatment. A TGF beta-like bioactivity was detected in control culture media, the concentration of which increased with the time of culture.

Conclusion: These results indicate that TGF beta-I did not change greatly, if any, the yield of the first meiotic division but likely enhanced a bottleneck at the level of metaphase II. Taken together, our results suggest strongly that TGF beta participates in an auto/paracrine pathway of regulation of the meiotic differentiation of rat spermatocytes.

\section{Background}

Multiplication, differentiation and survival or death of testicular germ cells are tightly regulated processes. Over the last decades it has become obvious that, in addition to the regulation exerted by the pituitary hormones (mainly FSH and LH) [1], spermatogenesis is under the control of a complex network of factors originating from both the somatic cells and the germ cells of the testis [2,3]. 
Moreover, it is becoming clear that hormones and intratesticular factors may compensate at least in part, for the absence of some hormones or factors, including FSH [4-6] and androgen [7-10] or luteinizing hormone [11] receptors. Thus, it is likely that synergism and/or redundancy between regulatory molecules is a characteristic of the spermatogenic process. Since most of the growth factors, cytokines and neurotrophins produced within the testis are widely expressed in the organism, the attempts to understand their role in spermatogenesis by knock-out strategies have been often disappointing. Transforming growth factor (TGF $\beta$ ) is an example of such molecules. TGF $\beta 1$, TGF $\beta 2$ and TGF $\beta 3$ are expressed in the male gonad and their receptors are present in the rat testis in both somatic cells and germ cells [12-16]. TGF $\beta$ - or TGF $\beta$ receptor-null mice have been created [17-23]. However, as these mice do not survive longer than a few weeks, their usefulness for studying spermatogenesis is limited. Hence, use of culture systems associating spermatogenic cells and testicular somatic cells might be a valuable alternative to study the possible involvement of intratesticular factors such as the TGF $\beta$ s on some step(s) of spermatogenesis. We [24,25] and others [26-28] have demonstrated that meiosis can proceed in vitro when mammalian spermatogenic cells are cocultured with Sertoli cells. In rodents, the kinetic of the meiotic process is similar in vivo and during the first week of culture $[24,26,29]$ and round spermatids developed in vitro can produce normal offspring [30]. Such culture systems have allowed to study some cellular aspects of the meiotic process [31] or of its regulation [32]. Hence, in the present work, we addressed the role of TGF $\beta 1$ on the completion of meiosis by rat pachytene spermatocytes cultured together with Sertoli cells.

\section{Methods \\ Isolation and co-culture of rat Sertoli cells and pachytene spermatocytes or round spermatids}

Co-cultures of 21-day old rat Sertoli cells and adult rat pachytene spermatocytes (PS) or round spermatids (RS) were performed in bicameral chambers as described by Weiss et al. [24]. More than 90\% of the cells in the PS fraction were $4 \mathrm{C}$ cells and more than $80 \%$ in the RS fraction were $1 \mathrm{C}$ cells; moreover, we found previously that $13 \%$ of elutriated PS were early PS (stages XIV-IV), 61\% were middle PS (stages V-IX) and 26\% were late spermatocytes (stages X-XIII) [32]. In some experiments, adult rats were injected with 5-bromo-2'-deoxyuridine (BrdU, SigmaAldrich, St Quentin Fallavier, France) (50 mg/kg) 14 days before they were killed, in order to label PS/diplotene spermatocytes of stages VII-XIII [32]. Under these conditions, BrdU-labelled stages XI, XII, and XIII (the only stages containing spermatocytes which may have time to differentiate into RS over a 3-day culture period $[24,26,29])$ represented $18 \%$ of the total number of stages containing BrdU-labelled PS/diplotene spermatocytes.
These procedures were approved by the Scientific Research Agency (approval $n^{\circ}$ 69306) and conducted in accordance with the guidelines for care and use of laboratory animals.

Cells were cultured in Dulbecco's Modified Eagle's Medium (F12/DMEM) supplemented with antibiotics, $\mathrm{NaHCO}_{3}(13.4 \mathrm{mM})$, insulin $(10 \mu \mathrm{g} / \mathrm{ml})$, transferrin $(10$ $\mu \mathrm{g} / \mathrm{ml})$, vitamin $\mathrm{C}\left(10^{-4} \mathrm{M}\right)$, vitamin $\mathrm{E}(10 \mu \mathrm{g} / \mathrm{ml})$, testosterone $\left(10^{-7} \mathrm{M}\right)$, retinoic acid $\left(3.3 \times 10^{-7} \mathrm{M}\right)$, retinol $(3.3$ $\left.\times 10^{-7} \mathrm{M}\right)$, pyruvate $(1 \mathrm{mM})$ (all products from SigmaAldrich, St Quentin Fallavier, France), and ovine NIH FSH-20 $(1 \mathrm{ng} / \mathrm{ml})$ obtained through NIADDK at $33^{\circ} \mathrm{C}$ in an humidified atmosphere of $95 \%$ air : $5 \% \mathrm{CO}_{2}$. In TGF $\beta 1$-treated wells, human recombinant TGF $\beta 1$ (10 ng/ ml) (R\&D Systems, Lille, France) was added in both the apical and the basal compartments of the bicameral chamber. Only basal media (with or without $10 \mathrm{ng} / \mathrm{ml}$ TGF $\beta 1$ ) were renewed every two days; TGF $\beta 1$ was added to the apical media at the same interval.

\section{Immunolabeling of cells for flow cytometry}

At selected days of culture, cells were detached from culture wells by trypsinization. After counting and determination of cell viability by Trypan blue exclusion, cells were fixed with ice cold $70 \%$ ethanol.

Immunolabeling of cultured cells and flow cytometric analyses were performed as described by Vigier et al. [32] and Godet et al. [33]. After washing with phosphate-buffered saline (PBS), fixed cells were resuspended in permeabilizing buffer $(0.25 \%$ Triton X-100/1\% BSA/PBS) for 20 minutes on ice. The cells were then exposed to an antivimentin antibody (clone V9 - Dako SA, Trappes, France) at a dilution of 1:500 in blocking buffer (5\% fetal calf serum/1\% BSA/PBS) for $3 \mathrm{~h}$ at $4^{\circ} \mathrm{C}$. After 3 washes in $1 \%$ $\mathrm{BSA} / \mathrm{PBS}$, the cells were incubated with fluorescein (FITC)-conjugated rabbit anti-mouse immunoglobulins (Dako SA, Trappes, France) diluted 1:60 in blocking buffer for 1 hour at $4^{\circ} \mathrm{C}$. Before analysis, Hoechst 33342 (Sigma-Aldrich, St Quentin Fallavier, France) was added to the labeled cell suspension at a final concentration of $20 \mu \mathrm{g} / \mathrm{ml}$.

\section{Flow cytometric and computer analyses}

After immunolabeling, cells were analysed using a FacsStar plus Cytometer (Becton Dickinson, Le Pont de Claix, France) equipped with a 50-mW argon laser tuned to 448 $\mathrm{nm}$ and an INNOVA 300 ion multilined/UV laser tuned to UV. Emission of fluorescence was measured with a DF 530/30 filter for FITC, and a DF 42/44 filter for Hoechst 33342. Data acquisition and analysis were performed with CellQuest software (Becton Dickinson, Le Pont de Claix, France). Four data parameters were acquired and stored in list mode files: linear forward light scatter (FSC) 
Table I: Sequences of the primers used to amplify mRNAs for TPI, p2I and I6S RNA

\begin{tabular}{ccc}
\hline \multicolumn{1}{c}{ RNA } & Primers & Product size(nt) \\
\hline TPI [EMBL: X07284]* & $5^{\prime}{ }_{26}-$ CCAGCCGCAAACTAAAGACTCATGG $-3^{\prime}$ & I75 \\
& $5^{\prime}{ }_{200}-$ AGCTCATTGCCGCATTACAAGTGGG - 3' & I45 \\
\hline P2I [EMBL: NM080782]* & $5^{\prime}{ }_{107}-$ GACCTGTTCCACACAGGAGCAAAGT - 3' & \\
\hline I6S [EMBL: XM34I8I5]* & $5^{\prime}{ }_{251}-$ GTCTCAGTGGCGAAGTCAAAGTTCC - 3' & 268 \\
\hline
\end{tabular}

nt : nucleotides

* gene bank accession numbers.

and linear side angle light scatter (SSC) which roughly represent cell size and cellular granularity, respectively; logarithmic FITC (vimentin) to detect immunolabeling, and linear Hoechst to measure the DNA content of the different cell populations. Contaminating events such as debris and clumped cells were eliminated from the analysis. Each acquisition was performed on 50000 cells negative for vimentin and allowed to identify $1 \mathrm{C}, 2 \mathrm{C}$ and $4 \mathrm{C}$ germ cells. Hence, the percentage of each category of germ cells was multiplied by the total number of cells per well in order to obtain the absolute number $1 \mathrm{C}, 2 \mathrm{C}$ and $4 \mathrm{C}$ cells.

\section{RNA extraction}

Total RNA from cultured cells was extracted according to Chomczynski and Sacchi [34], using Trizol Reagent (Invitrogen, Cergy-Pontoise, France). The purity and the integrity of the RNA were checked spectroscopically and by gel electrophoresis respectively.

\section{Reverse transcription-polymerase chain reaction (RT- PCR)}

Sequences corresponding to TP1 mRNA [EMBL: X07284] or p21 mRNA [EMBL: NM080782] and 16S rRNA [EMBL: XM341815] were amplified by RT-PCR as follows. Single strand $\mathrm{cDNAs}$ were obtained from reverse transcription (RT) of $1 \mu \mathrm{g}$ of total RNA in a final volume of $10 \mu \mathrm{l}$ containing $100 \mathrm{IU}$ of Moloney murine leukaemia virus reverse transcriptase (MMLVRT), $1.25 \mathrm{mM}$ dNTPs, $0.4 \mu \mathrm{g}$ of oligo-dT, $10 \mathrm{mM}$ DTT and 15 IU of RNase Guard (all products from Invitrogen, Cergy-Pontoise, France). RT was performed for 1 hour at $37^{\circ} \mathrm{C}$. A sample in which RNA was replaced by sterile water was used as a negative control.

\section{TPI//6S}

coamplification reactions were carried out on $80 \mathrm{ng}$ of reverse-transcribed RNA in a final volume of $30 \mu \mathrm{l}$ containing 1,5 IU of Taq DNA Polymerase (Roche Diagnostic,
Mannheim, Germany), $2 \mu \mathrm{M}$ dNTPs, $1 \mu \mathrm{Ci}$ [33P]dATP (Amersham Biosciences, Orsay, France) and $12.5 \mathrm{pmol}$ of each of the sequence-specific primers for TP1 and 16S (Sigma-Aldrich, St Quentin Fallavier, France) (Table 1). Amplification was performed in 5 sequential cycles (16, $18,19,20$ and 22 cycles) at $94^{\circ} \mathrm{C}$ for 1 minute, $58^{\circ} \mathrm{C}$ for 1 minute and $72{ }^{\circ} \mathrm{C}$ for 1 minute.

\section{p2III6S}

coamplification reactions were carried out on $80 \mathrm{ng}$ of reverse-transcribed RNA in a final volume of $30 \mu \mathrm{l}$ containing 1,5 IU of Taq DNA Polymerase (Roche Diagnostics), $3 \mu \mathrm{M}$ dNTPs, $1.5 \mu \mathrm{Ci}$ [33P]dATP (Amersham Biosciences) and $12.5 \mathrm{pmol}$ of the sequence-specific primers for p21 (Sigma-Aldrich) (Table 1). In a first step, amplification was performed for 6 cycles at $94^{\circ} \mathrm{C}$ for 1 minute, $58^{\circ} \mathrm{C}$ for 1 minute and $72^{\circ} \mathrm{C}$ for 1 minute. Then, $12.5 \mathrm{pmol}$ of the sequence-specific primers for $16 \mathrm{~S}$ were added and amplification was continued and performed in 5 sequential cycles $(20,22,24,2628$ cycles $)$.

The amplified products were electrophoresed in parallel with size markers on 3\% Metaphor Agarose gels (Tebu, Le Perray-en-Yvelines, France). The bands were cut from the gels and melted in distilled water at $100^{\circ} \mathrm{C}$. Radioactivity was measured using a liquid scintillation counter.

\section{TGF $\beta$ bioassay}

TGF $\beta$ concentrations in apical culture media were determined using mink lung epithelial cell (CCl-64), according to Danielpour et al. [35]. Briefly, CCl-64 cells were maintained in $75 \mathrm{~cm}^{2}$ flasks in F-12 DMEM medium supplemented with $10 \%$ foetal calf serum. In $0.32-\mathrm{cm}^{2}$ wells (96well plate), aliquots $(5-10 \mu \mathrm{l})$ of conditioned medium heated (or not) at $80^{\circ} \mathrm{C}$ for 5 minutes were added in 100 $\mu \mathrm{l}$ assay medium supplemented with $5 \%$ foetal calf serum. After 1 hour at $37^{\circ} \mathrm{C}, \mathrm{CCl}-64$ cells in logarithmic growth phase were trypsinised, washed once with assay medium, and plated at $3.10^{4}$ cells $/ 100 \mu \mathrm{l}$ in wells. CCl-64 
cells were cultured overnight, followed by pulse labelling with $\left[{ }^{3} \mathrm{H}\right]$ thymidine $(40-60 \mathrm{Ci} / \mathrm{mmol}$; Amersham Biosciences, Orsay, France) at a final concentration of $1 \mu \mathrm{Ci} /$ $\mathrm{ml}$ for 4 hours at $37^{\circ} \mathrm{C}$. The cells were fixed three times with $250 \mu \mathrm{l}$ methanol-acetic acid (3:1, vol/vol) and were washed twice with $80 \%$ methanol. ${ }^{3} \mathrm{H}$-labeled DNA was extracted by $250 \mu \mathrm{l} 0.4 \%$ deoxycholate $0.5 \mathrm{~N} \mathrm{NaOH}$. Radioactivity was measured by a liquid scintillation counter. In some cases TGF $\beta$ bioactivity of culture media was determined in the presence of a TGF $\beta 1 / 2 / 3$ blocking antibody (clone 1D11, R\&D Systems, Lille, France).

\section{Immunocytochemical studies on cultured cells}

At selected days of culture, cells were fixed directly in the well with Bouin's fixative for 20 minutes at room temperature.

\section{I-Immunocytochemical reaction against phosphorylated Histone $\mathrm{H} 3$} (pH3)

After washing with PBS, fixed cells were permeabilized with $0.03 \%$ TritonX-100 in PBS for 30 minutes. The immunocytochemical reaction was performed with the Dako LSAB kit (Dako SA, Trappes, France) as follows. Cells were incubated with $3 \% \mathrm{H}_{2} \mathrm{O}_{2}$ for 5 minutes, rinsed with PBS, then incubated with a monoclonal mouse antipH3 antibody (Upstate Biotechnology, Euromedex, Mundolsheim, France) at 1:200 dilution in Dako's antibody diluent for 3 hours at room temperature. After three washes with PBS, the staining reaction was performed using the avidin-biotin-peroxydase complex and amino3-ethyl-9-carbazole (AEC) as a chromogen.

\section{2-BrdU immunochemical reaction}

The same protocol as described above was performed, but denaturation of DNA was required before the immunoreaction. Cells were incubated for 5 minutes with $\mathrm{NaOH}$ $0,07 \mathrm{~N}$ diluted in alcohol:water (v:v) and then dipped in PBS for 10 minutes. Cells were incubated with a monoclonal mouse anti-bromodeoxyuridine antibody (Dako SA, Trappes, France) diluted 1:100 overnight at $4^{\circ} \mathrm{C}$. After three washes with PBS, the staining reaction was performed using avidin-biotin-peroxidase complex and AEC as a chromogen.

The membrane of the insert was cut off and mounted in Dako aqueous mounting medium.

The morphologic identification and counting of the different types of germ cells was performed as previously described [32].

\section{Statistical analysis}

ANOVA was used to compare between data from more than two groups. Paired Student's t test was used to assess statistical differences between control and TGF $\beta 1$-treated cells.

\section{Results}

Effects of TGF $\beta$ I on the number and viability of total germ cells and somatic cells

When about $3.10^{5}$ purified PS were cocultured with about $3.10^{5}$ Sertoli cells, both the number of total cells (somatic cells plus germ cells) and their viability decreased slightly during the culture period, as expected [24]. For both parameters, the decreases were similar in control and TGF $\beta 1$-treated cultures. On day 7 , the percentages of cells, compared with day 1 , were $79 \pm 8$ and $79 \pm 10 \%(\mathrm{~m} \pm$ SEM, $\mathrm{n}=7$ ) for controls and treated cells; the viabilities were $71 \pm 4$ and $69 \pm 3 \%$, respectively. Every day they were studied, the percentages of germinal cells and of somatic cells were similar in control and TGF $\beta 1$-treated cultures but the percentage of germ cells decreased during the culture, whereas that of somatic cells increased 1.3 fold (data not shown). This indicates that germinal cells were lost at a similar rate irrespective the culture conditions, whereas the number of somatic cells remained constant during the culture period.

\section{Effects of TGF $\beta$ I on the number of germ cells of different ploidy and on the amount of TPI mRNA}

The number of seeded PS (4C cells) decreased 2.5 fold between day 1 and day 7 in control and TGF $\beta 1$-treated cultures (both $\mathrm{p}<0.01$ ) and no difference was observed between these two conditions on any studied day (Fig. 1). Under our culture conditions, some of the PS differentiated into RS (1C cells) [24,31,32]. However, when TGF $\beta 1$ was added to the culture medium, the number of in vitro formed RS was significantly lower on days 5 and 7 than in control cultures ( $\mathrm{p}<0.01$ and $\mathrm{p}<0.05$ respectively). By contrast, no significant difference was ever observed in the population composed of secondary spermatocytes and of doublets of RS (2C cells) (Fig. 1). In addition, the amount of TP1 mRNAs (specific to the haploid state), assessed by the TP1/16S ratio on day 14 , of TGF $\beta 1$-treated cultures was lower than that of controls $(\mathrm{p}<0.05)$ (Fig. 2).

\section{Effects of TGF $\beta$ I on the survival of RS cultured with Sertoli cells}

Taken together, these results suggest that TGF $\beta 1$ inhibited the differentiation of PS into RS and/or affected the survival of RS. Therefore, in the next series of experiments, purified RS were cocultured with Sertoli cells for 5 days either in the absence or presence of TGF $\beta 1$ and the number of RS was determined daily between days 2 and 5. As expected [24,32], there was a steady decrease in the number of RS during the culture period. The regression line fitting the number of remaining RS on each day allowed the calculation of the half-life of RS which was identical in the absence or presence of TGF $\beta 1$ (Table 2). 

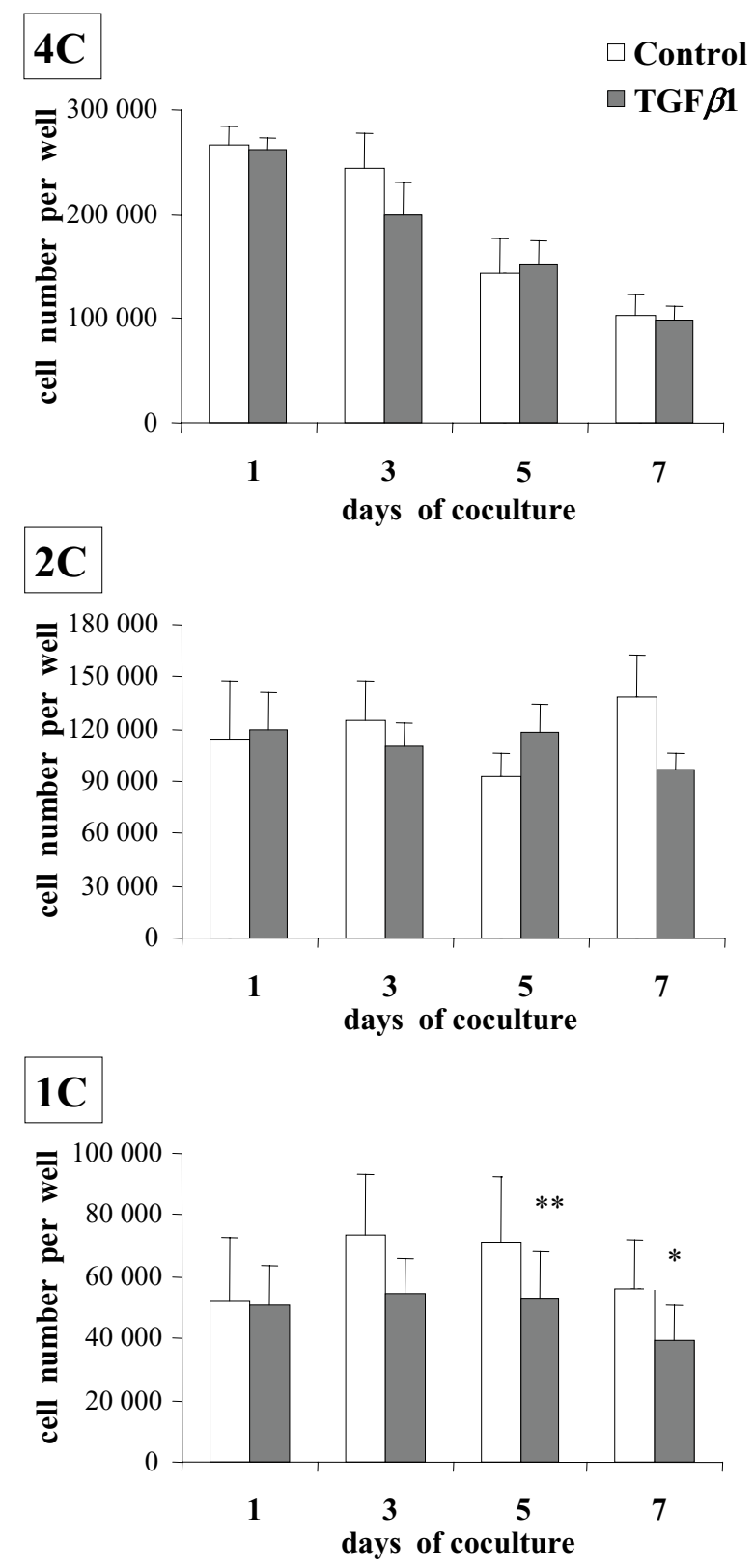

\section{Figure I}

Changes in the number of germ cells of different ploidy in cocultures of Sertoli cells and PS (4C cells) maintained in the absence (control) or presence of $10 \mathrm{ng} / \mathrm{ml} \mathrm{TGF} \beta \mathrm{I}$ (TGF $\beta \mathrm{I}$ ). Results are the mean \pm SEM of seven experiments. ${ }^{* *} \mathrm{p}<$ 0.0 I vs control; $* p<0.05$ vs control.

Effects of TGF $\beta$ I on the number of BrdU-labeled meiotic germ cells and the number of meiotic metaphases

Hence, the above results indicate that most likely, TGF $\beta 1$ was able to inhibit, at least partly, some step(s) in the dif-

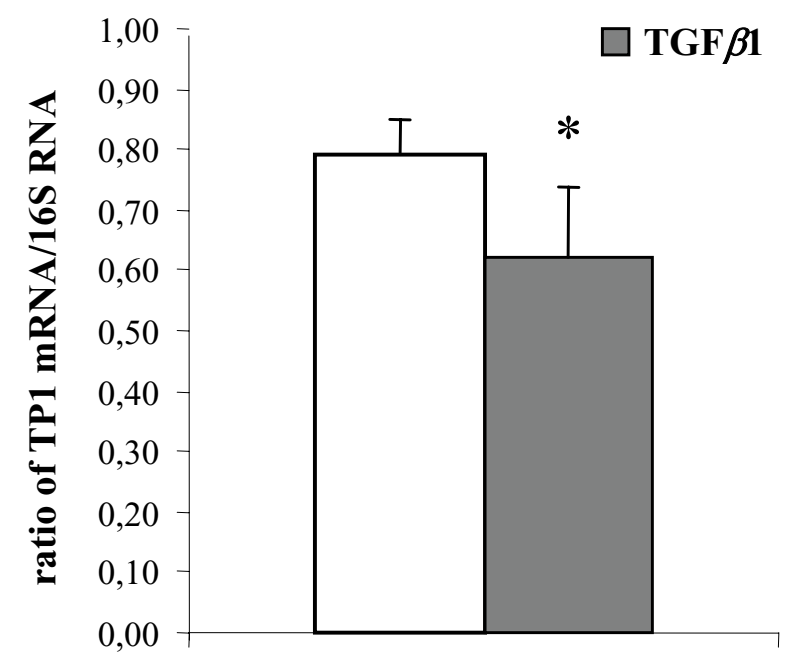

Figure 2

Effect of TGF $\beta$ I on the TPI mRNA/I6S rRNA ratio on day 14 of cocultures of Sertoli cells and PS. PS were cocultured with Sertoli cells for 14 days either in the absence (control) or presence of $10 \mathrm{ng} / \mathrm{ml}$ TGF $\beta I$. On day 14 of coculture, total RNA was extracted and TPI mRNA and I6S rRNA were coamplified by RT-PCR, as described in the Materials and Methods section, and their ratio were calculated. Each point is the mean \pm SEM of four experiments. ${ }^{*} p<0.05$ vs control.

Table 2: Half-lives of RS cocultured with Sertoli cells in the absence or presence of TGF $\beta$ I

\begin{tabular}{cc}
\hline Treatment & Half-life (days) \\
\hline Control & $1.9 \pm 0.2$ \\
TGF $\beta I$ & $1.9 \pm 0.2$ \\
\hline
\end{tabular}

Elutriated RS were cocultured with Sertoli cells for 5 days in the absence (control) or presence of $10 \mathrm{ng} / \mathrm{ml} \mathrm{TGF} \beta \mathrm{I}$ and the number of remaining RS was assessed by flow cytometry daily between day 2 and day 5 allowing the determination of their half-life in culture. Each value is the mean \pm SEM of three different experiments.

ferentiating pathway of PS into RS. In an attempt to identify this step, in the next experiments, BrdU-labeled PS/ diplotene spermatocytes of stages VII-XIII were cocultured with Sertoli cells in the absence or presence of TGF $\beta 1$; then, the number of BrdU-labeled PS, BrdU-labeled secondary spermatocytes (SII) and that of BrdU-labeled RS were assessed by microscopic examination. The data presented in Table 3 show that TGF 1 treatment modified 
Table 3: Numbers of BrdU-labeled PS, of BrdU-labeled secondary spermatocytes (SII) and BrdU-labeled RS on day I and day 3 of coculture of BrdU-labeled PS/diplotene spermatocytes of stages VII-XIII and Sertoli cells in the absence or presence of TGF $\beta$ I

\begin{tabular}{|c|c|c|c|c|c|c|c|c|c|c|c|c|}
\hline \multirow[b]{2}{*}{ Days of culture } & \multicolumn{3}{|c|}{ Number of PS/mm } & \multicolumn{3}{|c|}{ Number of SII/mm } & \multicolumn{3}{|c|}{ Number of RS/mm } & \multicolumn{3}{|c|}{ Number of metaphases } \\
\hline & - & & + & - & & + & & & + & - & & + \\
\hline$I(n=3)$ & $67.6 \pm 14.5$ & NS & $63.9 \pm 17.4$ & $1.3 \pm 0.3$ & NS & $1.7 \pm 0.3$ & $0.1 \pm 0.1$ & NS & $0.1 \pm 0.1$ & 0 & NS & 0 \\
\hline $3(n=7)$ & $42.7 \pm 5.1$ & NS & $33.4 \pm 6.1$ & $4.1 \pm 0.8$ & NS & $3.8 \pm 0.9$ & $5.7 \pm 1.3$ & $p<0.05$ & $4.2 \pm 1.3$ & $1.3 \pm 0.2$ & NS & $1.8 \pm 0.3$ \\
\hline
\end{tabular}

BrdU-labeled PS/diplotene spermatocytes were cocultured for 3 days in the absence (-) or presence (+) of $10 \mathrm{ng} / \mathrm{ml}$ TGF $\beta$ I. On days I and 3 , the numbers of BrdU-labeled PS, BrdU-labeled SII, BrdU-labeled RS and BrdU-labeled metaphases were determined by microscopic examination of the culture wells and expressed as the number of each cell type per $\mathrm{mm}$ of well and on the width of the microscope field (objective $\times 100)$. About 500 BrdU-labeled cells were counted in each condition and in each experiment.

Each value is the mean $\pm S E M ; n$ : number of experiments.

NS : not significant.

Table 4: Numbers of metaphase I and metaphase II on different days of coculture of PS and Sertoli cellsin the absence or presence of TGF $\beta$ I

\begin{tabular}{cllllll}
\hline & \multicolumn{2}{c}{ Number of metaphases I/mm } & \multicolumn{2}{c}{ Number of metaphases II/mm } \\
\hline $\begin{array}{c}\text { Days of } \\
\text { coculture }\end{array}$ & Control & & TGF $\beta$ I & Control & TGF $\beta$ I \\
\hline I & $0.09 \pm 0.02$ & NT & $0.03 \pm 0.01$ & $1.8 \pm 0.3$ & NS & $1.8 \pm 0.3$ \\
3 & $0.15 \pm 0.04$ & NT & $0.05 \pm 0.03$ & $2.3 \pm 0.3$ & $P<0.01$ & $3.1 \pm 0.4$ \\
5 & $0.04 \pm 0.02$ & NT & $0.03 \pm 0.01$ & $0.7 \pm 0.1$ & $P<0.05$ & $0.9 \pm 0.2$ \\
\hline
\end{tabular}

PS were cocultured for 5 days in the absence (control) or presence of $10 \mathrm{ng} / \mathrm{ml} \mathrm{TGF} \beta \mathrm{I}$. On days I, 3 and 5 , the numbers of metaphase I and of metaphase II were determined by microscopic examination of the culture wells and expressed as the number of each type per mm of well and on the width of the microscope field (objective $\times 100$ ). 400 to 1700 metaphase II were counted in each condition, whereas the number of metaphase I which could be counted ranged between 15 and 75 precluding meaningful statistical analysis.

Each value is the mean \pm SEM of 5 different experiments.

NS : not significant ; NT : not tested.

neither the number of PS nor the number of SII on any studied day, but decreased the number of RS on day 3 of culture. In addition, the number of metaphases seemed to increase a little on day 3 in the presence of TGF $\beta 1$.

Therefore in the next experiments, cultured cells were stained with a Ser 10 phosphorylated histone H3 antibody in order to label cells in the division phase [36,37] and the numbers of metaphase I and metaphase II were recorded at the level of the whole germ cell population, not only BrdU-labelled cells (Fig. 3 and Table 4). Very few meiotic metaphase I cells were ever observed both in control and in TGF $\beta 1$-treated cultures precluding meaningful statistical analysis. By contrast, higher numbers of metaphases II were present on any studied day. Furthermore, the number of metaphase II was significantly enhanced over control by TGF $\beta 1$ on days 3 and 5 of the experiment ( $\mathrm{p}<001$ and $\mathrm{p}<0.05$ respectively).

\section{Effects of TGF $\beta$ I on the expression of $p 2 I$ mRNA}

In an attempt to explore the mechanism of this inhibitory effect of TGF $\beta 1$ on the cell cycle of the meiotic cells, in the following experiments the amount of mRNA encoding for the cyclin-dependent kinase inhibitor p21waf1/cip1 was assessed on days 1, 2, and 3 of cocultures performed in the absence or presence of TGF $\beta 1$. The $\mathrm{p} 21 / 16 \mathrm{~S}$ ratio was similar in control and TGF $\beta 1$-treated cultures on any tested day (data not shown).

\section{Changes in the concentration of TGF $\beta$ bioactivity during coculture of PS with Sertoli cells}

Secretion of TGF $\beta 1$ by Sertoli cell-germ cell cocultures has been demonstrated by western blotting [38]. Therefore in the following experiments we studied whether a TGF $\beta$ like bioactivity was released under our culture conditions. No TGF $\beta$-like bioactivity could be detected in the media of the apical compartments of the culture chambers prior heat-treatment (data not shown). By contrast significant amounts were observed following heat activation; the concentration increased almost linearly with the time of culture from $0.8 \pm 0.1$ on day 3 , up to $4.0 \pm 0.2 \mathrm{ng} / \mathrm{ml}$ on day $15(\mathrm{~m} \pm \mathrm{SEM}, \mathrm{n}=3)$. This bioactivity was completely blocked by a TGF $\beta$ neutralizing antibody directed against TGF $\beta 1,2,3$ (data not shown). 

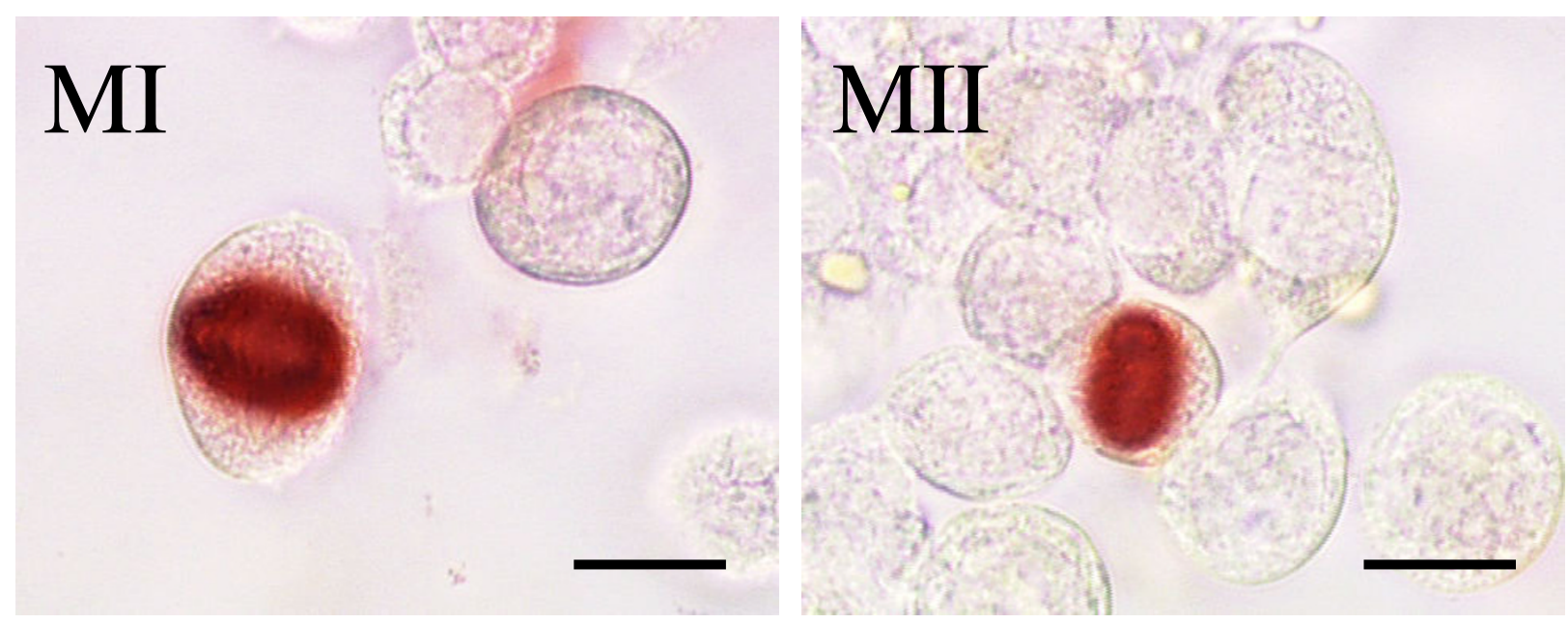

Figure 3

Staining of metaphase I (left) and metaphase II (right) by a Ser 10 phosphorylated histone $\mathrm{H}_{3}$ antibody in cocultures of PS and Sertoli cells (day one of coculture; bars represent $10 \mu \mathrm{m}$ ).

\section{Discussion}

To our knowledge, there has been no previous study on the effect of TGF $\beta$ on the meiotic differentiation of male germ cells. Yet it has been shown that germ cells synthesize TGF $\beta$ and are targets for the peptide (see [39] for review). However, TGF $\beta$-null mice die in pre-or neonatal stages, making it virtually impossible to investigate the significance of TGF $\beta$ in the late stages of spermatogenesis [17-23]; hence we have studied the effect of TGF $\beta$ on meiotic differentiation of spermatogenic cells by using a system of culture of rat PS previously established in our laboratory [24,31,32]. No effect of TGF $\beta 1$ was observed on the number of remaining PS or Sertoli cells on any day under our culture conditions. Likewise TGF $\beta 1$ did not modify the half-life of seeded RS. Hence, it seems reasonable to conclude that the lower number of RS observed in TGF $\beta 1$-treated wells was due to an inhibitory effect of this factor on the transformation of PS into RS. This assumption appears substantiated by the lower content in TP1 mRNAs (specific to the haploid state) of TGF $\beta 1$-treated cultures of 14 days. Screening of TP1 mRNA content was performed on day 14 for two reasons : i) the total number of RS in TGF $\beta 1$-treated cultures was significantly lower than in controls only from day 5 onward (Fig. 1). ii) We showed previously that expression of TP1 appears to be important only from steps 5-6 of spermiogenesis, that is, 4-5 days after completion of meiosis [40]. However, the possibility that TGF $\beta 1$ might decrease the transcription of TP1 and/or the half-life of its mRNA cannot be excluded.

An effect of TGF $\beta 1$ was observed only beyond one day of culture, which is the time necessary to the more advanced elutriated spermatocytes (stage XIII) to differentiate into secondary spermatocytes under our culture conditions [31], and affected the $1 \mathrm{C}$-cell population but not the $2 \mathrm{C}$ cell population. Moreover, cytological monitoring of the fate of BrdU-labeled PS showed that the numbers of SII were similar in the absence or presence of TGF $\beta 1$, whereas the number of BrdU-labeled metaphase seemed enhanced by this factor. This latter point was confirmed, at the level of the whole germ cell population, by use of a Ser 10 phosphorylated histone $\mathrm{H} 3$ antibody which allowed us to show that the number of second metaphases was enhanced in the presence of TGF $\beta 1$. Taken together, these results suggest that TGF $\beta 1$ did not change greatly, if any, the yield of the first meiotic division, but likely enhanced a bottleneck resulting in an increase in the number of metaphase II.

Progression of cells through the cell cycle requires assembly and activation of cyclin-CDK complexes [41]. CDK activity can be regulated by changes in cyclin or CDK levels, by post-translational modifications of the CDK subunit and by formation of a complex with a set of proteins 
called CKI [42]. P21 $1^{\text {waf1/cip1 }}$ belongs to the CKI family and binds to CDK2-cyclin A/E complexes [43] which are active during the G1 phase, S phase and/or the G2/M transition. Moreover, CDK2 and cyclin A1 appear essential for meiosis [44-46]. Several studies have shown that TGF $\beta 1$ induces $\mathrm{p} 21^{\text {waf1/cip } 1}$ expression $[47,48]$. In the testis, Beumer et al. [49] have suggested that $\mathrm{p} 21^{\mathrm{waf} 1 / \mathrm{cip} 1}$ could be important during the meiotic phase of spermatocytes as it is present in PS of stage V up to step 5 RS. As the work stands, we did not observe an increase in the amount of p21waf1/cip1 mRNA in TGF $\beta 1$-treated cultures. However, additional mechanisms appear able to mediate the cell cycle arrest caused by TGF $3[43,50-52]$.

In vivo, TGF $\beta 1$ is present mainly in spermatocytes and RS $[13,53]$ and rat testicular germ cells and Sertoli cells release different types of bioactive TGF $\beta$ s in vitro ( $[12,38,53]$ and present results).

Immunohistochemistry studies have localized both type I (T $\beta R I)$ and type II (T $\beta R I I)$ transducing receptors for TGF $\beta$ to the seminiferous epithelium in the rat testis $[12,15,16]$. Moreover, Smad2 and Smad3 that mediate intracellular signaling of the TGF $\beta$ superfamily from the cell surface to the nucleus are present in meiotic cells $[54,55]$ and TGF $\beta$ can regulate gene expression in these cells [56]. The amounts of TGF $\beta$-like bioactivity measured in our culture media fit quite well with those reported in cell culture supernatants of different testicular cell types by Haagmans et al. [53]. Moreover, these concentrations are quite in the range of the TGF $\beta$ concentrations required to regulate Cyp19 gene expression in isolated rat PS and RS [56] or to perturb the inter-Sertoli tight junction permeability barrier in vitro [57]. Furthermore, the work of Haagmans et al. [53] indicates that latent TGF $\beta$ released by primary cultures of germ cells and Sertoli cells can be converted into a bioactive form in the culture medium. Taken together, these results strongly suggest that TGF $\beta$ can be involved in an auto/paracrine pathway of regulation of the meiotic differentiation of rat spermatocytes. In experiments not reported here, we tried to inhibit the meiotic action of "endogenous" TGF $\beta$ with the anti-TGF $\beta$ antibody we used in the above bioassay ; however, the acid wash required to remove the antibody before counting the germ cells by either method precluded accurate analyses.

It might be argued that the effects of TGF 1 observed in the present study are relatively minor. However, it must be underlined that their amplitude is quite similar to the effects of TGF $\beta$ on $\left[{ }^{3} \mathrm{H}\right]$ thymidine incorporation by rat seminiferous tubule segments [58] or on the reduction of the number of rat gonocytes [59]. Moreover, it must be emphasized that the rather high standard errors of means, both in control and TGF $\beta 1$-treated cultures, were much more due to variations between the different experiments, as occurs often in vitro, than to variations of the effect of TGF $\beta 1$ treatments. Indeed, for instance, of the seven experiments reported in Fig. 1 or in Table 3 (day 3), six or seven exhibited a lower number of RS in TGF $\beta 1$-treated wells vs controls. Therefore it is not surprising that statistical analysis resulted in significant differences. In addition, it is clear that synergism and/or redundancy between local regulatory factors are a characteristic of the spermatogenic process $([2,32]$ and unpublished results). Hence it is not unexpected that many regulatory molecules, produced within the testis, may have somewhat limited effect when tested in the presence of the other factors regulating, in the same sense, the same step of spermatogenesis. As for the effects of TGF $\beta 1$ observed in the present work, two points should be emphasized: i)it is most likely that the amplitude of the effects of exogenous (added) TGF $\beta 1$ were limited by the TGF $\beta$ produced by our germ cell-Sertoli cell cocultures (see above); ii) in other studies not reported here, we observed that NGF, which is produced by PS and RS both in vivo $[60,61]$ and under our culture conditions (M.H. Perrard, unpublished results) is also able to negatively regulate the meiotic divisions of rat PS. Thus, it is very likely, that the presence of endogenous NGF also limited the effects of TGF $\beta 1$ observed in the present studies. Indeed, such a synergism/redundancy appears to be a major problem when exploring the local regulations of spermatogenesis which makes the knowledge of this topic far from being complete. Additional studies are now required to understand the mechanism of this action of TGF $\beta 1$ and why it is likely to be on the second meiotic division.

\section{Conclusion}

These in vitro results, together with previous studies showing the presence of TGF $\beta$ and its receptors in both the germ cells and the somatic cells of the male gonad, suggest strongly that TGF $\beta 1$ participates in an auto/paracrine pathway of regulation of the meiotic differentiation of rat spermatocytes.

\section{Authors' contributions}

$\mathrm{AD}$ participated in the design of the study, performed cultures and immunocytochemical and flow cytometry analyses and carried out PCR experiments. MHP participated in the design of the study, in the cultures and performed immunocytochemical studies. MV participated in the design of the study, in the cultures and in the PCR experiments, and performed TGF $\beta$ bioassays. OS carried out flow cytometry analyses. PD designed and coordinated the experiments, participated in the cultures, performed statistical analyses and drafted the manuscript. All authors read and approved the manuscript.

\section{Acknowledgements}

This work was supported by Institut National de la Santé et de la Recherche Médicale, Institut National de la Recherche Agronomique and Université 
Claude-Bernard Lyon I. AD was supported by the Ministère de l'Education Nationale, de l'Enseignement Supérieur et de la Recherche. We thank T. O'Neill for English revision and J. Bois for excellent secretarial assistance.

\section{References}

I. McLachlan RI, O'Donnell L, Meachem SJ, Stanton PG, de Kretser DM, Pratis K, Robertson DM: Identification of specific sites of hormonal regulation in spermatogenesis in rats, monkeys, and man. Recent Prog Horm Res 2002, 57: 149-I79.

2. Mauduit C, Benahmed M: Growth factor in the testis : development and function. In Research in Male Gametes : Production and Quality Edited by: Hamamah S and Mieusset R. Paris, INSERM; 1996:3-45.

3. Parvinen $M$, Ventela S: Local regulation of spermatogenesis: $\mathbf{a}$ living cell approach. Hum Fertil |999, 2: | 38-|42.

4. Kumar TR, Wang Y, Lu N, Matzuk MM: Follicle stimulating hormone is required for ovarian follicle maturation but not male fertility. Nat Genet 1997, I 5:201-204.

5. Dierich A, Sairam MR, Monaco L, Fimia GM, Gansmuller A, LeMeur $M$, Sassone-Corsi $P$ : Impairing follicle-stimulating hormone (FSH) signaling in vivo: targeted disruption of the FSH receptor leads to aberrant gametogenesis and hormonal imbalance. Proc Natl Acad Sci U S A 1998, 95:13612-13617.

6. Abel MH, Wootton AN, Wilkins V, Huhtaniemi I, Knight PG, Charlton HM: The effect of a null mutation in the follicle-stimulating hormone receptor gene on mouse reproduction. Endocrinology 2000, |41:1795-1803.

7. Yeh S, Tsai MY, Xu Q, Mu XM, Lardy H, Huang KE, Lin H, Yeh SD, Altuwaijir S, Zhou X, Xing L, Boyce BF, Hung MC, Zhang S, Gan L, Chang C: Generation and characterization of androgen receptor knockout (ARKO) mice: an in vivo model for the study of androgen functions in selective tissues. Proc Natl Acad Sci U S A 2002, 99: I 3498-I3503.

8. Chang C, Chen YT, Yeh SD, Xu Q, Wang RS, Guillou F, Lardy H, Yeh $S$ : Infertility with defective spermatogenesis and hypotestosteronemia in male mice lacking the androgen receptor in Sertoli cells. Proc Natl Acad Sci U S A 2004, I 0 I :6876-688I.

9. De Gendt K, Swinnen JV, Saunders PT, Schoonjans L, Dewerchin M, Devos A, Tan K, Atanassova N, Claessens F, Lecureuil C, Heyns W Carmeliet P, Guillou F, Sharpe RM, Verhoeven G: A Sertoli cellselective knockout of the androgen receptor causes spermatogenic arrest in meiosis. Proc Natl Acad Sci U S A 2004 | 0 |: | 327- | 332 .

10. Holdcraft RW, Braun RE: Androgen receptor function is required in Sertoli cells for the terminal differentiation of haploid spermatids. Development 2004, I 3 I:459-467.

II. Zhang FP, Pakarainen T, Poutanen M, Toppari J, Huhtaniemi I: The low gonadotropin-independent constitutive production of testicular testosterone is sufficient to maintain spermatogenesis. Proc Natl Acad Sci U S A 2003, I 00: I3692-I3697.

12. Mullaney BP, Skinner MK: Transforming growth factor-beta (beta 1 , beta 2 , and beta 3 ) gene expression and action during pubertal development of the seminiferous tubule: potential role at the onset of spermatogenesis. Mol Endocrinol 1993, 7:67-76.

13. Teerds KJ, Dorrington $\mathrm{JH}$ : Localization of transforming growth factor beta I and beta 2 during testicular development in the rat. Biol Reprod 1993, 48:40-45

14. Cupp AS, Kim G, Skinner MK: Expression and action of transforming growth factor beta (TGFbetal, TGFbeta2, and TGFbeta3) during embryonic rat testis development. Biol Reprod 1999, 60:1304-1313.

I5. Olaso R, Pairault C, Habert R: Expression of type I and II receptors for transforming growth factor beta in the adult rat testis. Histochem Cell Biol 1998, I 1 0:613-618.

16. Caussanel V, Tabone E, Hendrick JC, Dacheux F, Benahmed M: Cellular distribution of transforming growth factor betas I, 2 , and 3 and their types I and II receptors during postnata development and spermatogenesis in the boar testis. Biol Reprod 1997, 56:357-367.

17. Shull MM, Ormsby I, Kier AB, Pawlowski S, Diebold RJ, Yin M, Allen R, Sidman C, Proetzel G, Calvin D, Annunziata N, Doetschman T: Targeted disruption of the mouse transforming growth factor-beta I gene results in multifocal inflammatory disease. Nature 1992, 359:693-699.
18. Kulkarni AB, Huh CG, Becker D, Geiser A, Lyght M, Flanders KC, Roberts $A B$, Sporn MB, Ward JM, Karlsson S: Transforming growth factor beta I null mutation in mice causes excessive inflammatory response and early death. Proc Natl Acad Sci U S A 1993, 90:770-774.

19. Kaartinen V, Voncken JW, Shuler C, Warburton D, Bu D, Heisterkamp N, Groffen J: Abnormal lung development and cleft palate in mice lacking TGF-beta 3 indicates defects of epithelial-mesenchymal interaction. Nat Genet 1995, I |:4|5-42|

20. Sanford LP, Ormsby I, Gittenberger-de Groot AC, Sariola H, Friedman R, Boivin GP, Cardell EL, Doetschman T: TGFbeta2 knockout mice have multiple developmental defects that are nonoverlapping with other TGFbeta knockout phenotypes. Development 1997, I 24:2659-2670.

21. Oshima M, Oshima H, Taketo MM: TGF-beta receptor type II deficiency results in defects of yolk sac hematopoiesis and vasculogenesis. Dev Biol 1996, I 79:297-302.

22. Stenvers KL, Tursky ML, Harder KW, Kountouri N, AmatayakulChantler S, Grail D, Small C, Weinberg RA, Sizeland AM, Zhu HJ: Heart and liver defects and reduced transforming growth factor beta2 sensitivity in transforming growth factor beta type III receptor-deficient embryos. Mol Cell Biol 2003, 23:437। -4385.

23. Leveen P, Larsson J, Ehinger M, Cilio CM, Sundler M, Sjostrand LJ, Holmdahl R, Karlsson S: Induced disruption of the transforming growth factor beta type II receptor gene in mice causes a lethal inflammatory disorder that is transplantable. Blood 2002, I 00:560-568.

24. Weiss M, Vigier M, Hue D, Perrard-Sapori MH, Marret C, Avallet O, Durand P: Pre- and postmeiotic expression of male germ cellspecific genes throughout 2-week cocultures of rat germinal and Sertoli cells. Biol Reprod 1997, 57:68-76.

25. Staub C, Hue D, Nicolle JC, Perrard-Sapori MH, Segretain D, Durand $P$ : The whole meiotic process can occur in vitro in untransformed rat spermatogenic cells. Exp Cell Res 2000, 260:85-95.

26. Parvinen M, Wright WW, Phillips DM, Mather JP, Musto NA, Bardin $\mathrm{CW}$ : Spermatogenesis in vitro: completion of meiosis and early spermiogenesis. Endocrinology 1983, I I 2: I I50- I I 52.

27. Lee DR, Kaproth MT, Parks JE: In vitro production of haploid germ cells from fresh or frozen-thawed testicular cells of neonatal bulls. Biol Reprod 200I, 65:873-878.

28. Sousa M, Cremades N, Alves C, Silva J, Barros A: Developmental potential of human spermatogenic cells co-cultured with Sertoli cells. Hum Reprod 2002, I 7:161-172.

29. Perrard MH, Hue D, Staub C, Le Vern Y, Kerboeuf D, Durand P: Development of the meiotic step in testes of pubertal rats: comparison between the in vivo situation and under in vitro conditions. Mol Reprod Dev 2003, 65:86-95

30. Marh J, Tres LL, Yamazaki Y, Yanagimachi R, Kierszenbaum AL: Mouse round spermatids developed in vitro from preexisting spermatocytes can produce normal offspring by nuclear injection into in vivo-developed mature oocytes. Biol Reprod 2003, 69:169-176.

31. Godet M, Damestoy A, Mouradian S, Rudkin BB, Durand P: Key role for cyclin-dependent kinases in the first and second meiotic divisions of rat spermatocytes. Biol Reprod 2004, 70: | | 47- | I 52.

32. Vigier M, Weiss M, Perrard MH, Godet M, Durand P: The effects of FSH and of testosterone on the completion of meiosis and the very early steps of spermiogenesis of the rat: an in vitro study. J Mol Endocrinol 2004, 33:729-742.

33. Godet $M$, Thomas A, Rudkin BB, Durand P: Developmental changes in cyclin BI and cyclin-dependent kinase I (CDKI) levels in the different populations of spermatogenic cells of the post-natal rat testis. Eur J Cell Biol 2000, 79:816-823.

34. Chomczynski P, Sacchi N: Single-step method of RNA isolation by acid guanidinium thiocyanate-phenol-chloroform extraction. Anal Biochem 1987, I 62:156-159.

35. Danielpour D, Dart LL, Flanders KC, Roberts AB, Sporn MB: Immunodetection and quantitation of the two forms of transforming growth factor-beta (TGF-beta I and TGF-beta 2) secreted by cells in culture. J Cell Physiol 1989, I38:79-86.

36. Cobb J, Miyaike M, Kikuchi A, Handel MA: Meiotic events at the centromeric heterochromatin: histone $\mathrm{H} 3$ phosphorylation, topoisomerase II alpha localization and chromosome condensation. Chromosoma 1999, 108:412-425. 
37. Manzanero S, Arana P, Puertas MJ, Houben A: The chromosomal distribution of phosphorylated histone $\mathrm{H} 3$ differs between plants and animals at meiosis. Chromosoma 2000, I09:308-317.

38. Avallet O, Gomez E, Vigier M, Jegou B, Saez JM: Sertoli cell-germ cell interactions and TGF beta I expression and secretion in vitro. Biochem Biophys Res Commun 1997, 238:905-909.

39. Lui WY, Lee WM, Cheng CY: TGF-betas: their role in testicular function and Sertoli cell tight junction dynamics. Int J Androl 2003, 26: $147-160$

40. Marret C, Avallet O, Perrard-Sapori MH, Durand P: Localization and quantitative expression of mRNAs encoding the testisspecific histone TH2B, the phosphoprotein p 19, the transition proteins $I$ and 2 during pubertal development and throughout the spermatogenic cycle of the rat. Mol Reprod Dev |998, 5 I:22-35.

4I. Morgan DO: Cyclin-dependent kinases: engines, clocks, and microprocessors. Annu Rev Cell Dev Biol 1997, |3:26|-29|.

42. Vidal $A$, Koff $A$ : Cell-cycle inhibitors: three families united by a common cause. Gene 2000, 247:I-I5.

43. Gong J, Ammanamanchi S, Ko TC, Brattain MG: Transforming growth factor beta I increases the stability of p2 I/WAFI/ CIPI protein and inhibits CDK2 kinase activity in human colon carcinoma FET cells. Cancer Res 2003, 63:3340-3346.

44. Ortega S, Prieto I, Odajima J, Martin A, Dubus P, Sotillo R, Barbero JL, Malumbres $M$, Barbacid $M$ : Cyclin-dependent kinase 2 is essential for meiosis but not for mitotic cell division in mice. Nat Genet 2003, 35:25-3I.

45. Berthet C, Aleem E, Coppola V, Tessarollo L, Kaldis P: Cdk2 knockout mice are viable. Curr Biol 2003, I 3: I775-I785.

46. Liu D, Matzuk MM, Sung WK, Guo Q, Wang P, Wolgemuth DJ: Cyclin $A I$ is required for meiosis in the male mouse. Nat Genet 1998, 20:377-380.

47. Datto MB, Li Y, Panus JF, Howe DJ, Xiong Y, Wang XF: Transforming growth factor beta induces the cyclin-dependent kinase inhibitor p2l through a p53-independent mechanism. Proc Natl Acad Sci U S A 1995, 92:5545-5549.

48. Li CY, Suardet L, Little JB: Potential role of WAF I/Cip I/p2 I as a mediator of TGF-beta cytoinhibitory effect. J Biol Chem 1995, 270::497|-4974.

49. Beumer TL, Roepers-Gajadien HL, Gademan LS, Rutgers DH, de Rooij DG: P2I(CipI/WAFI) expression in the mouse testis before and after X irradiation. Mol Reprod Dev 1997, 47:240-247.

50. Geng $Y$, Weinberg RA: Transforming growth factor beta effects on expression of $\mathrm{GI}$ cyclins and cyclin-dependent protein kinases. Proc Natl Acad Sci U S A 1993, 90:10315-10319.

5I. Liu JH, Wei S, Burnette PK, Gamero AM, Hutton M, Djeu JY: Functional association of TGF-beta receptor II with cyclin B. Oncogene 1999, I 8:269-275.

52. Nagahara H, Ezhevsky SA, Vocero-Akbani AM, Kaldis P, Solomon MJ, Dowdy SF: Transforming growth factor beta targeted inactivation of cyclin E:cyclin-dependent kinase 2 (Cdk2) complexes by inhibition of Cdk2 activating kinase activity. Proc Natl Acad Sci U S A 1999, 96: |496|-|4966.

53. Haagmans BL, Hoogerbrugge JW, Themmen AP, Teerds KJ: Rat testicular germ cells and Sertoli cells release different types of bioactive transforming growth factor beta in vitro. Reprod Biol Endocrinol 2003, I:3

54. Hu J, Zhang YQ, Liu XP, Wang RA, Jin $Y, X u$ RJ: Expression and localization of Smad I, Smad2 and Smad4 proteins in rat testis during postnatal development. Asian J Androl 2003, 5:5 I-55.

55. Xu J, Beyer AR, Walker WH, McGee EA: Developmental and stage-specific expression of Smad2 and Smad3 in rat testis. J Androl 2003, 24:192-200.

56. Bourguiba S, Chater S, Delalande C, Benahmed M, Carreau S: Regulation of aromatase gene expression in purified germ cells of adult male rats: effects of transforming growth factor beta, tumor necrosis factor alpha, and cyclic adenosine 3',5'-monosphosphate. Biol Reprod 2003, 69:592-601.

57. Lui WY, Lee WM, Cheng CY: Transforming growth factor-beta 3 perturbs the inter-Sertoli tight junction permeability barrier in vitro possibly mediated via its effects on occludin, zonula occludens-I, and claudin-I I. Endocrinology 200 I, I 42: I865-I877.

58. Hakovirta $H$, Kaipia A, Soder O, Parvinen M: Effects of activin-A, inhibin-A, and transforming growth factor-beta I on stagespecific deoxyribonucleic acid synthesis during rat seminiferous epithelial cycle. Endocrinology 1993, I33: |664- I668.
59. Olaso R, Pairault C, Boulogne B, Durand P, Habert R: Transforming growth factor betal and beta2 reduce the number of gonocytes by increasing apoptosis. Endocrinology 1998, I39:733-740.
Publish with Biomed Central and every scientist can read your work free of charge

"BioMed Central will be the most significant development for disseminating the results of biomedical research in our lifetime. "

Sir Paul Nurse, Cancer Research UK

Your research papers will be:

- available free of charge to the entire biomedical community

- peer reviewed and published immediately upon acceptance

- cited in PubMed and archived on PubMed Central

- yours - you keep the copyright 